\title{
Microbiological Diagnosis of Prosthetic Joint Infections
}

\author{
Protez Eklem Enfeksiyonlarının Mikrobiyolojik Tanısı
}

\section{(1) Burçin ÖZER}

Hatay Mustafa Kemal University, Tayfur Ata Sökmen Faculty of Medicine, Department of Medical Microbiology, Hatay, Turkey

\section{Abstract}

Prosthetic joint infections (PJI) are the most important complication of joint replacement surgery. Diagnosis of PJI should be made with a multidisciplinary approach. Microbiological diagnostic methods must be used to isolate the causative microorganisms and to determine the antimicrobial susceptibility of these microorganisms. Microbiological methods used in preoperative diagnosis are blood culture, leukocyte count and type in synovial fluid and culture of synovial fluid. Those used in intraoperative diagnosis are cultures of abscesses, synovial fluid, soft tissue and bones located in and around prosthesis taken during the surgery. Other microbiological methods used in diagnosis of PJls are microcalorimetry, matrix assisted lazer desorption/ionization-time of flight mass spectrometry, homogenization of tissue samples with glass beads, fluorescent in situ hybridization, synovial biomarkers, enzymatic template generation and amplification. Also, various molecular methods such as $16 \mathrm{~S}$ rRNA sequencing analysis and polymerase chain reaction methods can be used for diagnosis of PJI. The aim of this review was to discuss the microbiological diagnostic methods of PJI in the light of current literatures.

Keywords: Microbiology, prosthesis, joint infections, diagnosis

\section{$\ddot{0} z$}

Protez eklem enfeksiyonları (PE) eklem replasman cerrahisinin en önemli komplikasyonlarından birisidir. Protez eklem enfeksiyonlarının tanısı multidisipliner bir yaklaşım ile yapılmalıdır. Etken mikroorganizmaların izole edilmesi ve bu mikroorganizmaların antimikrobiyal duyarılıklarının belirlenmesi için mutlaka mikrobiyolojik tanı yöntemleri kullanılmalıdır. Protez eklem enfeksiyonlarının preoperatif tanısında kullanılan mikrobiyolojik yöntemler; kan kültürü, eklem sıvısının lökosit sayısı ve tipi ve eklem sıvısının kültürüdür. İntraoperatif tanıda kullanılanlar ise ameliyat sırasında alınan protez ve çevresinden alınan abse, eklem sıvısı, yumuşak doku ve kemiklerden alınan örneklerin kültürüdür. Protez eklem enfeksiyonlarında kullanılan diğer mikrobiyolojik yöntemler mikrokalorimetre, matriks aracılı lazer dezorpsiyon/iyonizasyon uçuş zamanlı kütle spektrometresi, cam boncuk ile doku örneklerinin homojenizasyonu, floresan in situ hibridizasyon, sinoviyal biyomarkerlara bakılması, enzimatik kalıp oluşturma ve amplifikasyonudur. Ayrıca polimeraz zincir reaksiyonu 16S rRNA sekanslama analizi gibi çeşitli moleküler yöntemler PE tanısında kullanılabilir. Bu derlemenin amacı güncel literatürler eşliğinde PE'nin mikrobiyolojik tanı yöntemlerinin tartışılmasıdır.

Anahtar Kelimeler: Mikrobiyoloji, protez, eklem enfeksiyonları, tanı

\section{Introduction}

Joint replacement surgery is a major surgery performed to increase mobility and reduce pain in patients with degenerative joint diseases such as osteoarthritis ${ }^{[1]}$. Prosthetic joint infections
(PJI) are a complication that develops after joint replacement surgery, resulting in high morbidity and high $\operatorname{cost}^{[2]}$. Prosthetic joint infections prolongs hospital stay, requires additional surgery and antimicrobial therapy, increases the cost of treatment, and may even lead to death ${ }^{[3]}$.

Cite this article as: Özer B. Microbiological Diagnosis of Prosthetic Joint Infections. Mediterr J Infect Microb Antimicrob. 2021;10:24. 
Treatment success rates for PJI can be increased if early diagnosis can be made. On the other hand, delayed diagnosis can usually lead to decreased function, increased morbidity, and the need for more complex surgery ${ }^{[2]}$. A single clinical and laboratory test that is routinely used in the diagnosis of PJI has not been shown to have the ideal sensitivity, specificity, and to make definitive diagnosis. Therefore, a combination of laboratory, histopathological, microbiological, and imaging studies is usually required ${ }^{[4]}$. Thanks to microbiological diagnostic methods, the causative microorganism can be detected and its antimicrobial sensitivity can be detected. Since knowing the antimicrobial sensitivity of the microorganism increases the success in treatment, microbiological diagnosis is very important ${ }^{[4-6]}$.

Microbiological diagnosis in $\mathrm{PJI}$ is divided into two as preoperative and intraoperative $e^{[7,8]}$. Leukocyte count and acute phase reactants such as C-reactive protein (CRP) and erythrocyte sedimentation rate (ESR) are used as screening tests in preoperative diagnosis ${ }^{[9]}$. Although leukocyte count and ESR are not microbiological diagnostic methods, they will also be briefly mentioned. Blood culture, swab culture and examination and culture of joint fluid are also laboratory procedures used in preoperative diagnosis. In intraoperative diagnosis, samples taken during surgery should be cultured ${ }^{[9,10]}$.

\section{A. Tests Used in Preoperative Diagnosis}

The first screening tests used in the evaluation of PJI due to its widespread use and low cost are; serum leukocyte count and type, CRP, and $\mathrm{ESR}^{[8-10]}$.

\section{Leukocyte Count and Type}

The sensitivity of serum leukocyte count is 55\% and specificity is $66 \%$ in PJI. The sensitivity of the leukocyte type is $52 \%$ and its specificity is 75\%. Although it is useful in detecting the infection, its sensitivity and specificity are low because it cannot show the focus completely ${ }^{[9,11]}$. Although routine laboratory examinations contain findings in favor of infection, leukocytosis may not be present. Studies have shown that serum leukocyte count and type do not play a role in the diagnosis of $\mathrm{PJ}\left[{ }^{[9,11]}\right.$.

\section{Erythrocyte Sedimentation Rate}

It is the rate at which erythrocytes settle to the bottom of the test tube in saline or plasma. It is a simple and inexpensive test. It is one of the oldest and most frequently used laboratory tests ${ }^{[12]}$. Its normal value is $15 \mathrm{~mm} /$ hour in men and $20 \mathrm{~mm} /$ hour in women. Its increase is often associated with infections, inflammations, and malignancies ${ }^{[12]}$. ESR increases after surgery and remains high for a long time. Since factors such as anemia, macrocytosis, polycythemia, spherocytosis, acanthocytosis, microcytosis, hypoalbuminemia will affect ESR and it will take a long time to rise and return to normal values after surgery, its sensitivity in PJI varies between $54-82 \%$ and specificity between $65-85 \% \%^{[12,13]}$.

\section{C-Reactive Protein}

It is an acute phase reactant in the structure of globulin synthesized in the liver. It can increase 15-40 times compared to normal in invasive bacterial infections. It generally increases 3-5 times in viral infections, and there may be more than 10 times increase in viral infections such as cytomegalovirus and tissue involvement such as myocarditis. In addition to infectious diseases, CRP increases 5-20 times in systemic vasculitis and malignancies (especially lymphomas) ${ }^{[14]}$. It increases in a short time in case of inflammation and tissue destruction and decreases rapidly when the situation improves. It peaks on the second day after surgery, returns to normal in two to three weeks. Although there is often parallelism between ESH and CRP; CRP is a more specific indicator in inflammatory events as it is less affected by conditions such as anemia, macrocytosis, polycythemia, spherocytosis, congestive heart failure, hypergammaglobulinemia ${ }^{[14]}$. CRP is a more valuable test in diagnosing PJl. Its sensitivity is $80-96 \%$ and its specificity is 93-100\% ${ }^{[15]}$. Values higher than $10 \mathrm{mg} / \mathrm{dl}$ should be interpreted in favor of infection. Although there is PJI; CRP level may be low in case of suppressive antimicrobial therapy, low virulence pathogens, chronic infections, and infections with fistulae $\mathrm{e}^{[15]}$. It may increase significantly due to concomitant inflammatory conditions and after primary uncomplicated arthroplasty. If both ESR and CRP are within normal values, periprosthetic infection can be ruled out ${ }^{[15]}$. If both are elevated, PJI may be present and further investigations should be done. If ESR is more than $30 \mathrm{~mm} /$ hour and CRP is more than $10 \mathrm{mg} / \mathrm{dl}$, sensitivity for PJI increases to $97.6 \% \%^{[15]}$. The diagnostic sensitivity of CRP and ESR may vary depending on the type of prosthesis or surgery. The diagnostic sensitivity of CRP and ESR in infections developing in knee arthroplasty and spine implantation is higher than the diagnostic sensitivity of CRP and ESR in hip PJI. Its sensitivity in the diagnosis of shoulder arthroplasty infections is low ${ }^{[15-17]}$. This may be the result of the low virulent organism Propionibacterium acnes being a frequent agent in shoulder arthroplasty infection or it may be related to the failure to use optimized cut-off values for shoulder arthroplasty infection. In the clinical guide prepared by the Infectious Diseases Society of America (IDSA) for PJI; when clinical diagnosis is not clear, ESR and CRP tests are recommended for all patients with suspected PJI. The combination of abnormal ESR and CRP provides the highest sensitivity and specificity (A-3) (Table 1) $)^{[18-20]}$.

\section{Interleukin-6}

Interleukin-6 (IL-6) is secreted from macrophages, Th2 cells, B cells, and endothelial cells. Its concentration in peripheral blood increases after trauma, chronic inflammatory conditions and 
arthroplasty. Interleukin-6 can be used to detect infection and monitor treatment response in the early postoperative period. Interleukin-6 levels above $12 \mathrm{pg} / \mathrm{ml}$ together with high CRP levels can be a good screening test in $\left.\mathrm{PJ}\right|^{[3,21,22]}$. One advantage of determining serum IL-6 levels is that it quickly returns to normal shortly after joint arthroplasty. The half-life of CRP is 62 hours, while the half-life of IL- 6 is 15 hours ${ }^{[23]}$.

\section{Procalcitonin}

It is the prohormone of calcitonin synthesized in the thyroid gland. It is secreted from mononuclear cells as a response to bacterial lipopolysaccharide, and from liver cells with the stimulation of tumor necrosis factor- $\alpha$ (TNF- $\alpha$ ) and IL-6. It is normally found in very low amounts such as $<0.05 \mathrm{ng} / \mathrm{ml}$. During infection, this value rises above $0.5 \mathrm{ng} / \mathrm{ml}$. In severe infections (bacterial, parasitic and fungal) with systemic symptoms, it can rise above $100 \mathrm{ng} / \mathrm{ml}^{[8]}$. While viral infections, inflammatory events and localized bacterial infections lead to a slight increase, it is found that there is a significant increase in systemic bacterial infections. It is useful in distinguishing noninfectious causes of fever from infections. Serum procalcitonin levels do not increase significantly after arthroplasty. It has no value in diagnosing $\mathrm{PJ}{ }^{[8-11]}$.

\section{Blood Cultures}

In patients with suspected PJI, febrile patients, or if there is a suspicion of metastatic infection, two or more blood culture sets or repeated samples should be taken. Blood culture is positive in only $20 \%$ of patients with PJI. Blood cultures are rarely positive in patients without systemic sepsis findings ${ }^{[19,20]}$. In IDSA guidelines; blood culture is recommended if there is fever, acute onset symptoms, concomitant infection, pathogen (e.g. S. aureus) isolated, suspected infective endocarditis or cardiac pacemaker ${ }^{[20]}$.

\section{Preoperative Synovial Fluid}

If there is increase in ESR and CRP in hip replacement and if there is increase in ESR and/or CRP in knee prosthesis; synovial fluid is taken by arthrocentesis. Leukocyte count is made in the joint fluid. If the leukocyte count is $>1700$ cells $/ \mu$, the sensitivity for $\mathrm{PJI}$ is $94 \%$ and the specificity is $88 \% \%^{[15]}$. Synovial fluid is analyzed by staining with Gram and Giemsa methods. Leukocyte types are determined. If the neutrophil dominance is more than $65 \%$, the sensitivity for $\mathrm{PJI}$ is $97 \%$ and the specificity is $98 \% 0^{[15,16]}$. The synovial fluid sent to the microbiology laboratory should also be cultured. If the synovial fluid is examined and cultured, the sensitivity is $82-94 \%$ and the specificity is $94-97 \%$. In order to increase the chance of reproduction of the microorganism in culture, inoculation should also be done in a pediatric blood culture bottle.

In the examination of periprosthetic frozen tissue at 400 magnification under a microscope, the sensitivity of detecting more than five neutrophils in each area is more than $80 \%$ and the specificity is more than $90 \%$. The most important limitation of histopathological examination is that the causative microorganism cannot be detected. It is very important to isolate the causative microorganism and to perform its antibiogram in order to arrange the appropriate treatment ${ }^{[15,16]}$.

Preoperative aspiration and culture of synovial fluid and identification of the causative microorganism have a sensitivity of $82-94 \%$ and a specificity of $94-97 \%$. However, using antimicrobials 2-3 weeks before aspiration increases the number of false negative synovial fluid cultures ${ }^{[15]}$.

According to IDSA, analysis of synovial fluid should include total cell count and determination of leukocyte type as well as culture for aerobic and anaerobic microorganisms A-3 $)^{[18-20]}$. Discontinuation of antimicrobial therapy at least two weeks before collecting synovial fluid for culture increases the detection of the microorganism in patients $(\mathrm{B}-3)^{[18-20]}$.

\section{Other Cultures}

In superficial wound or sinus tract cultures, there may be microbial colonization from the surrounding skin. It is not helpful as it cannot detect those that cause deep infections. In culture taken from the sinus tract, the pathogen can be detected

Table 1 . Strength of recommendation and quality of evidence

\begin{tabular}{ll}
\hline Category/degree & Definition \\
\hline Strength of recommendation \\
\hline A & Good evidence in favor of or against use to support a recommendation \\
\hline B & Moderate evidence in favor of or against use to support a recommendation \\
\hline C & Poor evidence to support a recommendation \\
\hline Quality of evidence & \\
\hline 1 & $>1$ correct randomized evidence, controlled trial \\
\hline 2 & Evidence from dramatic results from 1 well-designed clinical trial without randomization, cohort or case-controlled \\
& analytical studies (preferably from >1 center), multiple time series or uncontrolled experiments \\
\hline 3 & Evidence from authorities' views based on clinical experience, descriptive studies, or reports from expert committees \\
\hline
\end{tabular}


at low rates. Only $S$. aureus isolation from the sinus tract is significant ${ }^{[24]}$. The culture of aspirated synovial fluid can detect $45-100 \%$ of the microorganism, and this rate can be increased by seeding in a pediatric blood culture bottle. While 62 pathogens were isolated from those inoculated in a blood culture bottle, it was reported that 57 pathogens were isolated in the agar plate method $^{[26]}$. If antibiotic treatment is discontinued at least two weeks before the samples are collected, the detection of microorganisms increases ${ }^{[23]}$.

\section{B. Tests Used in Intraoperative Diagnosis}

\section{Culture}

During the operation, samples can be taken from the prosthesis and its surrounding from abscess, synovial fluid, soft tissue, and bones ${ }^{[20]}$. If the components of the prosthesis are also to be removed, they should be sent to the laboratory for culture. Biopsy samples should be taken from at least three different places. The sensitivity of the cultures of the samples taken with swabs is low and biopsy samples should be preferred. Samples should be collected with separate sterile instruments and placed in separate sterile containers. It should be sent to the laboratory as fast as possible. Transport media should be used if anaerobic conditions are required. More pathogens can be detected by inoculating synovial fluid into pediatric blood culture bottles than direct culture methods ${ }^{[19,20]}$. Isolation of the same microorganism from two or more independent samples is a strong indicator of infection. Antibiotic treatment should be discontinued two weeks before taking the sample for culture, as it will be difficult to detect the organism in the sample with ongoing antibiotic treatment. Perioperative prophylaxis should not be initiated in revision surgery before tissue samples are taken for culture ${ }^{[20]}$.

Histopathological examination can help identify PJI and acute inflammation. However, it cannot detect the causative microorganism. Histopathological examination of periprosthetic tissue samples is a reliable diagnostic test for the interpretation of periprosthetic tissue ${ }^{[23]}$. At least 3 and optimally 5 or 6 periprosthetic intraoperative tissue samples or aerobic and anaerobic culture of the removed prosthesis should be requested $(B-2)^{[18-20]}$. Intraoperative culture samples taken at least two weeks before antimicrobial treatment will increase its acquisition $(A-2)^{[18-20]}$.

Rapid recognition of the agent with intraoperative Gram staining may be recommended, but Gram staining is positive in less than 1/3 of the patients. Gram staining of tissue samples has low sensitivity $(26 \%)$ and high specificity $(97 \%)^{[13,15,20]}$.

PJI is divided into three as early, delayed and late infections according to their development time ${ }^{[9,15,16]}$. Early infections are infections seen before three months. In early infections, the agent is usually microorganisms in the flora of the patient and healthcare workers and in the operating room environment, and they cause infection by direct inoculation ${ }^{[9,15,16]}$. The most frequently isolated microorganisms in infections seen in this period are $S$. aureus and Gram-negative bacilli[15,16,20,27]. Delayed infections occur between three months and two years and coagulase negative staphylococci are the most frequently isolated microorganisms in infections during this period. Late infections, on the other hand, spread by hematogenous way. During the processes and infections of the genitourinary and gastrointestinal systems, Gram-negative bacilli, especially Enterobacteriaceae and Pseudomonas aeruginosa, and Enterococcus spp. and anaerobic bacteria can cause PJI by spreading hematogenously. While viridans streptococci, Peptococcus spp. and Peptostreptococcus spp. cause PJI, Streptococcus spp. may cause PJI during pyogenic skin infections ${ }^{[15,16]}$. Unusual pathogens such as Polymicrobial infection and Candida spp., Brucella spp., and Mycobacteria have also been reported. No microorganism can be produced in a significant part of it. Antimicrobial agents are used in most of them ${ }^{[4,15,16,20,27]}$.

Prosthetic joint infections are divided into four according to the onset time and clinical symptoms ${ }^{[27,28]}$.

I. Positive intraoperative culture: Growth of the same microorganism in at least two cultures taken during the operation.

II. Early postoperative infection: Infection that develops within one month after the operation. It is divided into superficial and deep early postoperative infection. Coagulase negative staphylococci and $S$. aureus are the factors in superficial infections. In deep infections, $S$. aureus, coagulase negative staphylococci and Gram-negative bacilli are causative agents. III. Acute hematogenous infection: An infection with symptoms of acute infection in a well-functioning joint. S. aureus and Streptococci are causative agents.

IV. Late chronic infection: An infection that develops one month after the operation, with subacute and insidious clinical symptoms. S. aureus, coagulase negative staphylococci and Gram-negative bacilli are causative agents.

Microorganism may not grow in culture as a result of wrong sampling, small number of microorganisms in patients who are treated with antibiotics, use of inappropriate media, delay in processing of sample, and in biofilm-related PJI. Microorganism isolation chance can be increased by sonication applied before culture in biofilm-related PJ|[29].

Implant-related infections are typically caused by microorganisms that grow in structures known as biofilms. 
Biofilm consists of self-organizing microorganisms with selfproduced exopolymer saccharides attached to surfaces with altered phenotypes. Especially S. aureus and coagulase negative staphylococci can form biofilms. Biofilm microbes are 10-1000 times less sensitive to antimicrobials, especially agents acting on the cell wall. High concentrations of antibacterial agents may be required to destroy microorganisms embedded in biofilms ${ }^{[2]}$.

\section{Sonication and Culture of the Prosthesis}

Prostheses, joint components, bones, pins, screws that are removed during the operation are placed in a sterile container. They are coated with ringer lactate or saline. Sound waves with a wavelength of $40 \pm 2 \mathrm{kHz}$ are applied on the sonication device for five minutes ${ }^{[29]}$. Before sonication, the liquid containing the prosthesis is vortexed and inoculated from the liquid to suitable media. After five minutes of sonication, it is vortexed again and inoculated on suitable media. If the number of microorganisms increases after sonication, there is an infection associated with biofilm ${ }^{[29]}$. The sensitivity of periprosthetic tissue culture is $60.8 \%$ and its specificity is $99.2 \%$. The sensitivity and specificity of sonicated liquid culture is higher $(78.5-98.8 \%)^{[20]}$. Sonication is not widely used in routine identification centers. There is a risk of contamination during the process. Vortexing process does not harm bacteria. It may be beneficial to vortex the instrument even without sonication. By sonication of the removed prosthesis, especially the bacteria forming biofilms are separated from the prosthesis surface. Ultrasonic culture of the prosthesis can increase the sensitivity of aerobic and anaerobic culture compared to traditional tissue cultures ${ }^{[20]}$.

Gram staining, which has low sensitivity in tissue samples, is not routinely useful as a diagnostic test. Gram stain is more sensitive in sonicated liquid. False positive Gram staining may occur due to laboratory contamination ${ }^{[20]}$.

\section{Treatment of Prosthesis and Its Components with Dithiothreitol}

Dithiothreitol (DTT) can be used as an alternative to sonication ${ }^{[30]}$. $0.1 \% \mathrm{DT}$ in sterile phosphate buffered saline is placed on the prosthesis and its components. It is shaken at $80 \mathrm{rpm}$ for 15 minutes. Cultures are made for aerop and anaerobic bacteria. Sonication and DTT administration are more sensitive than standard tissue cultures. Its sensitivity is $89 \%$ and its specificity is $91 \%{ }^{[31]}$.

The PJI diagnostic criteria and scoring systems of the Musculoskeletal Infection Society, International Consensus Meeting are shown in Table 2 and the PJI diagnostic criteria and scoring systems of IDSA, and The European Bone and Joint Infection Society are summarized in Table $3^{[18,19,32-34]}$.

Table 2. The prosthetic joint infection diagnostic criteria and scoring systems of the Musculoskeletal Infection Society, International Consensus Meeting ${ }^{[21]}$

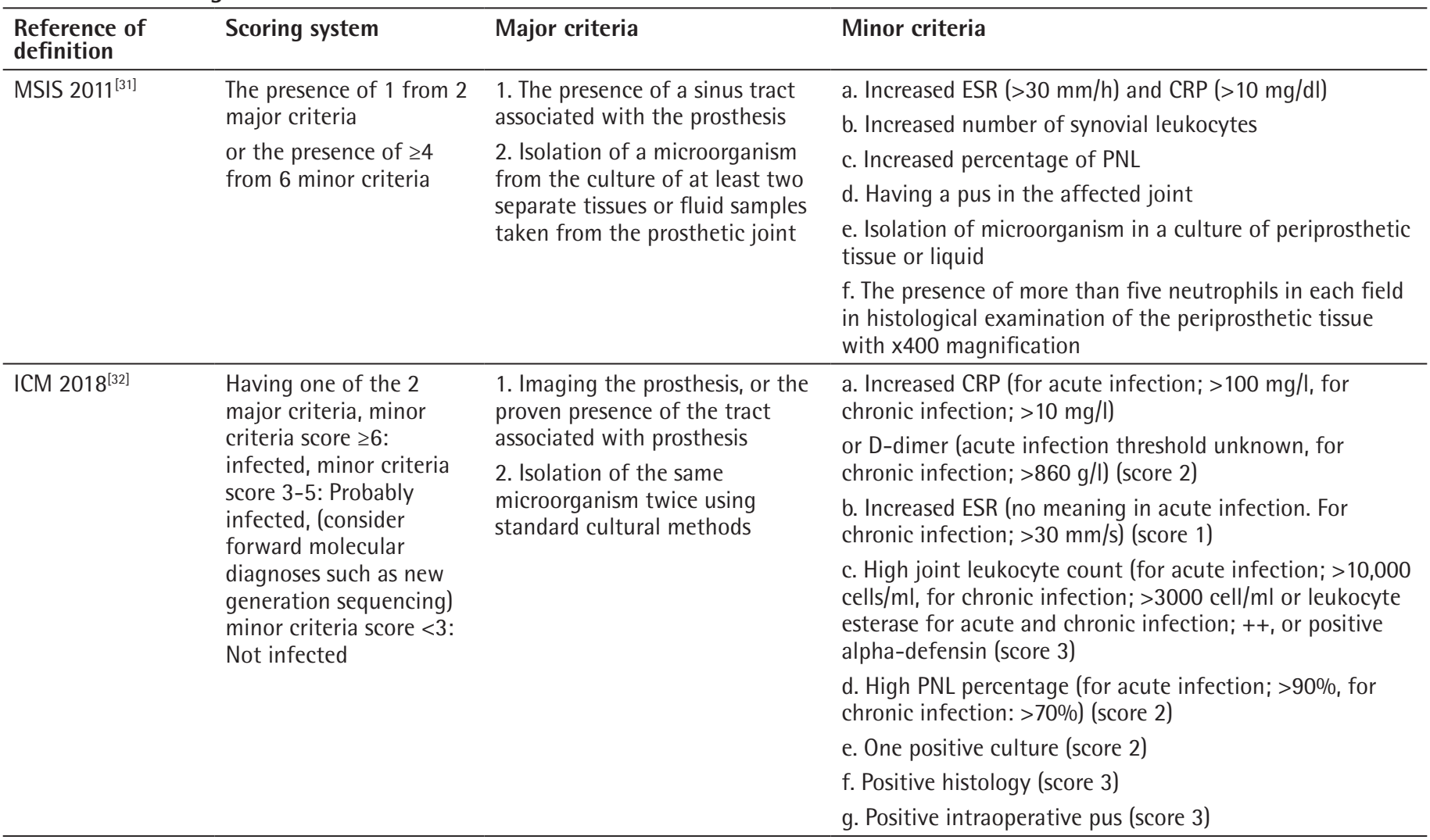

MSIS: Musculoskeletal Infection Society, ICM: International Consensus Meeting, CRP: C-reactive protein, ESR: Erythrocyte sedimentation rate 
The sensitivity and specificity of the tests used in prosthetic infections are shown in Table 4.

\section{Other Methods That Can Be Used in the} Diagnosis of Prosthetic Infections

\section{Microcalorimeter}

It measures the intensity of heat generated in relation to the growth and metabolism of dividing microorganisms in real time. In vitro analysis has shown that it can be an accurate, noninvasive, real-time microbiological test for detecting biofilms.
With microcalorimetric analysis of synovial fluids taken from patients with acute arthritis, septic and non-septic arthritis can be differentiated within 8-10 hours ${ }^{[8]}$.

\section{Matrix Assisted Lazer Desorption/Ionization-time of Fight Mass Spectrometry}

The Matrix assisted lazer desorption/ionization-time of flight mass spectrometry (MALDI-TOF) method, which facilitates the analysis of large macromolecules including nucleic acids and proteins, is based on the principle of ionizing the specific protein structures of microorganisms and forming protein fingerprints

Table 3. The prosthetic joint infection diagnostic criteria and scoring systems of Infectious Diseases Society of America, and The European Bone and Joint Infection Society ${ }^{[21]}$

\begin{tabular}{|c|c|c|}
\hline $\begin{array}{l}\text { Reference of } \\
\text { definiton }\end{array}$ & Scoring system & Criteria \\
\hline \multirow[t]{4}{*}{ IDSA $2013^{[20]}$} & \multirow{4}{*}{$\begin{array}{l}\text { More than one positive } \\
\text { criterion }\end{array}$} & 1. The presence of a sinus tract associated with the prosthesis \\
\hline & & 2. The presence of pus without other etiological factors surrounding the prosthesis \\
\hline & & 3. Acute inflammation in histopathological examination of periprosthetic tissue \\
\hline & & $\begin{array}{l}\text { 4. Microorganisms in two or more intraoperative cultures or microorganisms together in } \\
\text { preoperative aspiration and intraoperative cultures }\end{array}$ \\
\hline \multirow[t]{4}{*}{ EBJIS 2018 } & \multirow{4}{*}{$\begin{array}{l}\text { More than one positive } \\
\text { criterion }\end{array}$} & 1. The presence of pus surrounding the prosthesis and sinus tract \\
\hline & & 2. High leukocyte count in synovial fluid (>2000 cells/ml or $>70 \%$ granulocytes) \\
\hline & & 3. Positive histopathology \\
\hline & & $\begin{array}{l}\text { 4. Microbial reproduction in synovial fluid, periprostetic tissue, or sonication culture } \\
\text { (reproduction of high virulent microorganism in } \geq 1 \text { sample, or low virulent microorganism in } \geq 2 \\
\text { samples) }\end{array}$ \\
\hline
\end{tabular}

IDSA: Infectious Diseases Society of America, EBJIS: The European Bone and Joint Infection Society

Table 4. Tests used in diagnosis of prosthetic infection, and their sensitivity and specificity

\begin{tabular}{|c|c|c|c|c|}
\hline Timing & Tests & Sensitivity \% & Specificity \% & Reference number \\
\hline \multirow{10}{*}{ Preoperative } & Leukocyte type & 55 & 66 & 9,11 \\
\hline & Leukocyte type & 52 & 75 & 9,11 \\
\hline & ESR & $54-82$ & $65-85$ & 12,13 \\
\hline & CRP & $80-96$ & $93-100$ & 15 \\
\hline & $\mathrm{ESR}>30 \mathrm{~mm} / \mathrm{h}, \mathrm{CRP}>10 \mathrm{mg} / \mathrm{dl}$ & 97,6 & & 15 \\
\hline & Interleukin-6 & 100 & 86 & 20 \\
\hline & Procalcitonin & 33 & 98 & 20 \\
\hline & Number of leukocytes in synovial fluid $>1700$ cells $/ \mu$ l & 94 & 88 & 15 \\
\hline & Neutrophil in synovial fluid $\geq 65 \%$ & 97 & 98 & 15,16 \\
\hline & Synovial fluid culture & $82-94$ & $94-97$ & 19,20 \\
\hline \multirow{6}{*}{ Intraoperative } & Examination of tissue samples with Gram staining & 26 & 97 & $13,15,20$ \\
\hline & Periprosthetic tissue culture & 60.8 & 99.2 & 20 \\
\hline & Sonication and culture of the prosthesis & 78.5 & 98.8 & 20 \\
\hline & Sonication and culture of synovial fluid & 78.5 & 98.8 & 20 \\
\hline & Treatment of prosthesis and its components with dithiothreitol & 89 & 91 & 31 \\
\hline & Polymerase chain reaction & 91.2 & 92.3 & 19,20 \\
\hline
\end{tabular}


according to the time of flight. With this method, pathogenic microorganisms can be identified quickly. In this method, the protein structures of microorganisms are compared with the references in the database of the system ${ }^{[8,35]}$. This method is easily applicable, requires inexpensive reagents and can identify the microorganism in 15 to 30 seconds shortly after the sample is loaded ${ }^{[35]}$. If the microorganism can be identified early in PJI, targeted empirical therapy can be applied more precisely to reduce the emergence of resistant strains. Direct MALDI-TOF MS analysis of positive blood cultures with synovial fluid has the advantage of rapid pathogen identification. Studies have shown that the median time until direct MALDI-TOF MS identification in positive blood cultures in which synovial fluid is sown in PJI is significantly shorter ${ }^{[35,36]}$.

\section{Homogenization of Tissue Samples with Glass Beads}

It involves homogenization of tissue samples with glass beads to release intracellular pathogens from biofilms ${ }^{[8]}$.

\section{Fluorescent In Situ Hybridization}

Fluorescent in situ hybridization (FISH) and peptide nucleic acid probe can identify specific microorganisms in less than 1 hour in positive blood culture bottles. Combining FISH with confocal laser scanning microscopy creates 2D and 3D images of biofilms that can help evaluate the effectiveness of antimicrobial agents and offer great potential for the diagnosis of $\mathrm{PJ}{ }^{[8]}$.

\section{Synovial Biomarkers}

The use of synovial biomarkers is being investigated as fast and inexpensive diagnostic methods in $\left.\mathrm{PJ}\right|^{[8,34]}$. Synovial biomarkers can be divided into two main groups: Cytokines and biomarkers with antimicrobial functions. When infection occurs in the joint, cytokines such as interleukin-16, IL-6, interleukin-8, interleukin-17 and TNF- $\alpha$ are secreted from macrophages. These biomarkers have low specificity as they can be elevated in other inflammatory diseases of the joint such as rheumatoid arthritis. More specific synovial fluid biomarkers are leukocyte esterase, human $\alpha$-defensin, human $\beta$-defensin, and synovial $\operatorname{CRP}^{[37]}$.

\section{Enzymatic Template Generation and Amplification}

It is a new and rapid technology for the detection of living organisms in blood culture bottles. The technique determines the level of microbial DNA polymerase in clinical samples in less than three hours with a sensitivity of $90.6 \%$ and a specificity of $99.0 \% 0^{[8]}$

\section{Molecular Methods}

Various molecular methods such as polymerase chain reaction (PCR), 16S rRNA sequencing analysis and reverse transcription PCR have been used in the diagnosis of $\mathrm{PJI}{ }^{[8,34]}$. These are methods that are especially important in culture-negative infections or in the presence of spoiled microorganisms. Synovial fluid or tissue samples can be investigated with these techniques after sonication or homogenization with bead. The sensitivity of PCR is $91.2 \%$ and its specificity is $92.3 \%\left[0^{[8,19,20]}\right.$.

Other potentially useful technologies in development include microarray, phage-induced impedance fluctuation analysis, nanomedicine, and metabolomics ${ }^{[8]}$. These could potentially be applied in the future in the routine management of PJI. They not only identify pathogens, determine their virulence factors and antimicrobial susceptibility; but also show response to treatment as well as disease process and disease progression.

\section{Conclusion}

A combination of laboratory, histopathological, microbiological, and imaging studies is required to diagnose PJI. Microbiological diagnostic methods should definitely be used among the diagnostic methods to isolate the causative microorganism and determine the antimicrobial susceptibility of these microorganisms. Microbiological diagnostic methods of PJI are divided into preoperative and intraoperative diagnosis. Leukocyte count, CRP and ESR are used as screening tests in preoperative diagnosis. Microbiological methods used in preoperative diagnosis are; blood culture, leukocyte count and leukocyte type of the synovial fluid and the culture of the synovial fluid. In the intraoperative diagnosis, the prosthesis taken during the surgery and the samples taken from the surrounding abscess, synovial fluid, soft tissue and bones should be cultured. Biopsy specimens are preferred in these specimens. Microorganisms may not be produced in culture due to the biofilm produced by microorganisms that have a particular role in the development of PJI. The chance of isolation increases in cultures prepared after the treatment of prosthesis and its components with sonication and DT, which dissolve the biofilm layer. Other methods used in PJI are microcalorimetry, MALDI-TOF mass spectrometry, homogenization of tissue samples with glass beads, fluorescent in situ hybridization, synovial biomarkers, and enzymatic template generation and amplification. In addition, various molecular methods such as PCR and $16 \mathrm{~S}$ rRNA sequencing analysis can be used in the diagnosis of PJI.

\section{Ethics}

Peer-review: Externally and internally peer-reviewed.

Financial Disclosure: The author declared that this study received no financial support.

\section{References}

1. Tande AJ, Patela R. Prosthetic joint infection. Clin Microbiol Rev. 2014;27:302-45.

2. Esposito S, Leone S. Prosthetic joint infections: microbiology, diagnosis, management and prevention. Int J Antimicrob Agents. 2008;32:287-93.

3. Ersöz G. Orthopedic prosthetic infections. Klimik Dergisi. 2013;26:84-93. 
4. Cataldo MA, Petrosillo N, Cipriani M, Cauda R, Tacconelli E. Prosthetic joint infection: Recent developments in diagnosis and management. J Infect. 2010;61:443-8.

5. Legout L, Senneville E. Periprosthetic joint infections: clinical and bench research. Scientific World Journal. 2013;2013:549091.

6. Diktaş H, Turhan V. Orthopedic prosthetic infections: current approaches to diagnosis, treatment and management. Mediterr J Infect Microb Antimicrob. 2012;1:12.

7. Miller JM, Binnicker MJ, Campbell S, Carroll KC, Chapin KC, Gilligan PH, Gonzalez MD, Jerris RC, Kehl SC, Patel R, Pritt BS, Richter SS, RobinsonDunn B, Schwartzman JD, Snyder JW, Telford S, Theel ES, Thomson Jr RB, Weinstein MP, Yao JD. A guide to utilization of the microbiology laboratory for diagnosis of infectious diseases: 2018 update by the Infectious Diseases Society of America and the American Society for Microbiology. Clin Infect Dis. 2018;67:e1-94.

8. Saeed K. Diagnostics in prosthetic joint infections. J Antimicrob Chemother 2014;69(Suppl 1): i1-i19.

9. Cassar Gheiti AJ, Mulhall J. Peri-prosthetic joint infection: prevention, diagnosis and management. In: Kinov P (ed). Arthroplasty update, Chapter: 22. London: Intechopen Publisher, 2013:481-515.

10. Kandemir Ö. Prosthetic joint infections. ANKEM Derg. 2014;28(Ek 2):18-26.

11. Toossi N, Adeli B, Rasouli MR, Huang R, Parvizi J. Serum white blood cell count and differential do not have a role in the diagnosis of periprosthetic joint infection. J Arthroplasty 2012; 27(Suppl 8):51-4.

12. Kalayoğlu Beşışık S. Erythrocyte sedimentation rate. Nobel Medicus. 2005;1:4-9.

13. Otto-Lambertz C, Yagdiran A, Wallscheid F, Eysel P, Jung N. Periprosthetic infection in joint replacement diagnosis and treatment. Dtsch Arztebl Int. 2017;114:347-53.

14. Ghanem E, Antoci V, Jr. Pulido L, Joshi A, Hozack W, Parvizi J. The use of receiver operating characteristics analysis in determining erythrocyte sedimentation rate and C-reactive protein levels in diagnosing periprosthetic infection prior to revision total hip arthroplasty. Int J Infect Dis. 2009;13:444-9.

15. Esposito $\mathrm{S}$, Leone $\mathrm{S}$. Prosthetic joint infections: microbiology, diagnosis, management and prevention. Int J Antimicrob Agents. 2008;32:287-93.

16. Moran E, Byren I, Atkins BL. The diagnosis and management of prosthetic joint infections. J Antimicrob Chemother. 2010;65(Suppl 3):iii45-54.

17. Piper KE, Fernandez-Sampedro M, Steckelberg KE, Mandrekar JN, Karau MJ, Steckelberg JM, Berbari EF, Osmon DR, Hanssen AD, Lewallen DG, Cofield RH, Sperling JW, Sanchez-Sotelo J, Huddleston PM, Dekutoski MB, Yaszemski M, Currier B, Patel R. C-Reactive protein, erythrocyte sedimentation rate and orthopedic implant infection. PLoS One. 2010;5:e9358.

18. National Center for Health Statistics. National Hospital Discharge Survey: 2004 annual summary with detailed diagnosis and procedure data. National Center for Health Statistics, 2009. Available from: https://www.cdc.gov/ nchs/data/series/sr_13/sr13_162.pdf

19. Drago L, Clerici P, Morelli I, Ashok J, Benzakour T, Bozhkova S, Alizadeh C, Del Sel H, Sharma HK, Peel T, Mattina R, Romanò CL. The World Association against Infection in Orthopaedics and Trauma (WAIOT) procedures for Microbiological Sampling and Processing for Periprosthetic Joint Infections (PJIs) and other implant-related infections. J Clin Med. 2019;8:1-16.

20. Osmon DR, Berbari EF, Berendt AR, Lew D, Zimmerli W, Steckelberg JM, Rao $N$, Hanssen A, Wilson WR, Infectious Diseases Society of America. Diagnosis and management of prosthetic joint infection: clinical practice guidelines by the Infectious Diseases Society of America. Clin Infect Dis. 2013;56:1-10.
21. Dalkılıç E, Gül C.B, Alkış N. Interleukin-6: One of the Leading Actors on Inflammation. Uludağ Üniversitesi Tıp Fakültesi Dergisi 2012;38:157-60.

22. Di Cesare PE, Chang E, Preston CF, Liu CJ. Serum interleukin-6 as a marker of periprosthetic infection following total hip and knee arthroplasty. J Bone Joint Surg Am. 2005;87:1921-7.

23. Wirtz DC, Heller KD, Miltner O, Zilkens KW, Wolff JM. Interleukin-6: a potential inflammatory marker after total joint replacement. Int Orthop. 2000;24:194-6.

24. Marculescu CE, Cantey JR. Polymicrobial prosthetic joint infections risk factors and outcome. Clin Orthop Relat Res. 2008;466:1397-404.

25. Trampuz A, Steckelberg JM, Osmon DR, Cockerill FR, Hanssen AD, Patel R. Advances in the laboratory diagnosis of prosthetic joint infection. Rev Med Microbiol. 2003;14:1-14.

26. Hughes JG, Vetter EA, Patel R, C D Schleck, Harmsen S, Turgeant LT, Cockerill FR. Culture with BACTEC peds plus/f bottle compared with conventional methods for detection of bacteria in synovial fluid. J Clin Microbiol. 2001;39:4468-71.

27. Gül HC, Artuk C, Yıldız C. Diagnosis, treatment and management of prosthetic infections. J Clin Anal Med. 2013;4:332-9.

28. Tsukayama T, Goldberg VM, Kyle R. Diagnosis and Management of Infection After Total Knee Arthroplasty. J Bone Joint Surg. 2003;85-A(Suppl 1):75-80.

29. Evangelopoulos DS, Stathopoulos IP, Morassi GP, Koufos S, Albarni A, Karampinas PK, A Stylianakis, S Kohl, Pneumaticos S, Vlamis J. Sonication: a valuable technique for diagnosis and treatment of periprosthetic joint infections. Scientific World Journal. 2013;2013:375140.

30. Drago L, Signori V, De Vecchi E, Vassena C, Palazzi E, Cappelletti L, Romanò $\mathrm{D}$, Romanò CL. Use of dithiothreitol to improve the diagnosis of prosthetic joint infections. J Orthop Res. 2013;31:1694-9.

31. Sambri A, Cadossi M, Giannini S, Pignatti G, Marcacci M, Neri MP, Maso A, Storni E, Gamberini S, Naldi S, Torri A, Zannoli S, Tassinari M, Fantini M, Bianchi G, Donati D, Sambri V. Is treatment with dithiothreitol more efective than sonication for the diagnosis of prosthetic joint infection? Clin Orthop Relat Res. 2018;476:137-45.

32. Parvizi J, Zmistowski B, Berbari EF, Bauer TW, Springer BD, Della Valle CJ, Garvin KL, Mont MA, Wongworawat MD, Zalavras CG. New definition for periprosthetic joint infection: from the workgroup of the musculoskeletal infection society. Clin Orthop Relat Res. 2011;469:2992-4.

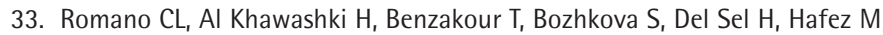
Johari A, Lob G, Sharma HK, Tsuchiya H, Drago L, World Association against Infection in Orthopedics and Trauma (W.A.I.O.T.) Study Group on Bone and Joint Infection Definitions. The W.A.I.O.T. Definition of High-Grade and Low-Grade Peri-Prosthetic Joint Infection. J Clin Med. 2019;8:650.

34. George DA, Drago L, Scarponi S, Gallazzi E, Haddad FS, Romano CL. Predicting lower limb periprosthetic joint infections: A review of risk factors and their classification. World J Orthop. 2017;8:400.

35. Buchan BW, Ledeboer NA. Emerging Technologies for the Clinical Microbiology Laboratory. Clin Microbiol Rev. 2014;27:783-822.

36. Wilcox MH. Overcoming barriers to effective recognition and diagnosis of Clostridium difficile infection. Clin Microbiol Infect. 2012;18(Suppl 6):1320.

37. Deirmengian $\mathrm{C}$, Hallab N, Tarabishy A, Della Valle $\mathrm{C}$, Jacobs JJ, Lonner J, Booth RE Jr. Synovial fluid biomarkers for periprosthetic infection. Clin Orthop Relat Res. 2010;468:2017-23. 